\title{
THE CRITICAL STATE OF AN INCLINED LAYER IN A SHEET SPECIMEN WITH NEGATIVE LOADING BIAXIALITY COEFFICIENT
}

\author{
V.L. Dilman, South Ural State University, Chelyabinsk, Russian Federation, \\ Dilman49@mail.ru, \\ A.N. Dheyab, South Ural State University, Chelyabinsk, Russian Federation, \\ Aws.nth@gmail.com
}

\begin{abstract}
We study conditions for the loss of stability in a plastic deformation of a layer of weaker material in a sheet specimen. The layer is not collinear with the exterior forces acting in the sheet plane, which are orthogonal to each other and have opposite signs. The parameters of the problem are: the angle between the layer and the direction of exterior forces; the ratio of stresses due to exterior forces; the ratio of strengths of the layer material and the main material of the sheet specimen; the strengthening law of the layer material; the ratio of thicknesses of the layer and the specimen. Basing on Swift's plastic instability criterion for a deformation of the layer material, we obtain an algorithm for calculating critical stress in the layer and critical exterior loading in dependence on the indicated parameters. When contact strengthening of the layer is absent, our results have explicit analytic expressions. We find conditions under which the layer does not lower the strength of the specimen. We find conditions for the stressed state of the layer to be a pure shear and study this case.
\end{abstract}

Keywords: inclined plastic layer; plastic instability; stress-strain state; Swift's criterion.

Introduction. To study the behavior of inhomogeneous constructions in the conditions of complicated stressed states is necessary for estimating their bearing capacity [1, 2]. One of the most efficient methods for calculating critical deformations and stresses for biaxial loading, corresponding to the loss of stability in a plastic deformation, proposed in [3], rests on the plastic instability criterion of [4]. Basing on refinements and development of the approach of [3], explicit analytic dependence of critical deformations, stresses, and pressure in homogeneous thin cylindrical hulls and sheet constructions were obtained in [5]. Welded thin hulls and sheets can include layers of weaker material: welded seams, fusion zones, thermal influence zones. The study of critical states of these joints relies on two theories: the theory of stability loss in a deformation of layer material $[2,3,5]$ and the theory of contact strengthening of the layer material [5-7]. The latter enables us to find the dependence of normal and tangent stresses $\sigma_{y}$ and $\tau_{x y}$ on the mechanical inhomogeneity coefficient $K=k^{+} / k^{-}$of the joint, as well as the contact strengthening coefficient $g$ of the layer. Here $k^{+}$and $k^{-}$are plasticity parameters of the main material and layer material characterizing the moment when plastic stability is lost.

Inclined layers are of practical interest. They lie at some angle to the direction of exterior mutually orthogonal loads generating the stresses $\sigma_{1}$ and $\sigma_{2}$. Welded seams, fusion zones, and thermal influence zones of the factory seams of twisted pipes are important 
examples of layers of this type. It is shown in [5] that for an inclined layer we can use the computational scheme of the case when the layer is orthogonal to one of the exterior loads. In this scheme, instead of the coefficient $K$ we should use the parameter $K_{\text {incl }}$ (see (5) below) depending on the mechanical and geometric characteristics of the joint and loading conditions. Assume that the following parameters are specified in the statement of the problem.

(1) The mechanical inhomogeneity coefficient $K$ of the joint.

(2) The slope $\nu$ of the layer (the angle between the directions of the layer and the action of the load $\sigma_{1}$, see Fig. 1).

(3) The relative thickness $\chi$ of the layer, that is, the ratio of its height (thickness) to its width (thickness of the sheet or hull).

(4) The loading biaxiality coefficient $m=\sigma_{1} / \sigma_{2}$.

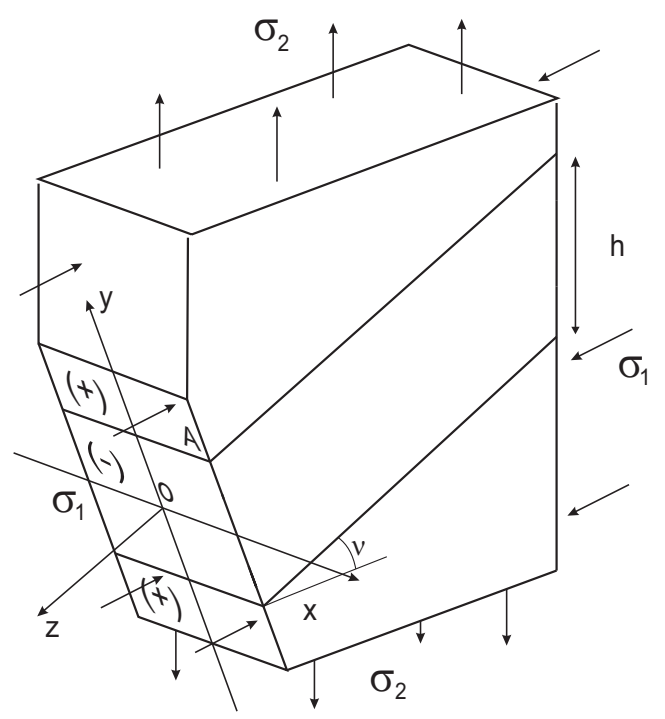

Рис. 1. Inclined layer in sheet specimen.

We determine the following parameters from the given conditions: the coefficient $g \geq 1$ of contact strengthening of the layer material, which depends on $\chi, K_{\text {incl }}$, and $\nu$, and the conditional mechanical inhomogeneity coefficient $K_{\text {incl }}$ also depending on $K$ and $\nu$.

Introduce some notation. Put

$$
B=\cos ^{2} \nu+m \sin ^{2} \nu ; \quad C=(1-m) \sin 2 \nu .
$$

For brevity, denote $\tau_{y z}$ by $\tau$. As indicated in [5, pp. 231, 232],

$$
\tau=0,5 C \sigma_{2} ; \sigma_{y a v}=B \sigma_{2} .
$$

Here $\sigma_{y \text { av }}=\int_{0}^{1} \sigma_{y}(x, \chi) d x$ is the mean value of the stress $\sigma_{y}$ on the contact surface. The reference also includes a formula introducing the contact strengthening coefficient $g$ :

$$
\sigma_{y \text { av }}=2 g \sqrt{\left(k^{-}\right)^{2}-\tau^{2}} .
$$

The von Mises plasticity condition for an inclined layer [5, p. 232] is

$$
\left(\sigma_{x}-\sigma_{y}\right)^{2}+\tau_{x y}^{2}=\left(k^{-}\right)^{2}-\tau^{2} .
$$


The analog of $K$, the conditional mechanical inhomogeneity coefficient [5, p. 233], is

$$
K_{\text {incl }}=\sqrt{\frac{\left(k^{+}\right)^{2}-\tau^{2}}{\left(k^{-}\right)^{2}-\tau^{2}}}=K \sqrt{1+\frac{K^{2}-1}{K^{2}} \frac{g^{2} C^{2}}{B^{2}}} .
$$

We consider the case $\tau=k^{-}$separately.

The restriction $m>0$ is imposed in [5, Ch. 4]. If $m \leq 0$ then the computational scheme of [5] is inapplicable. The goal of this article is to study the critical states of an inclined weak layer in a sheet specimen when $K_{\text {incl }}>1$ and $m<0$.

1. The Special Case of a Stressed State of the Layer. Equation (5) does not cover the case

$$
\begin{gathered}
|\tau|=k^{-}, \\
B=0 .
\end{gathered}
$$

Verify that (6) and (7) are equivalent conditions.

Proposition 1. $\tau=k^{-} \Leftrightarrow B=0 \Leftrightarrow m=-\operatorname{ctg}^{2} \nu$.

Proof. Suppose that $\tau=k^{-}$. Then (2) yields $\sigma_{2} \neq 0$ and (3) yields

$$
B=\frac{\sigma_{y a v}}{\sigma_{2}}=\frac{2 g \sqrt{\left(k^{-}\right)^{2}-\tau^{2}}}{\sigma_{2}}=0 .
$$

Conversely, if $B=0$ then (2) and (3) imply that $\sqrt{\left(k^{-}\right)^{2}-\tau^{2}}=0$. By (1), conditions (6) and (7) are equivalent to each of the conditions

$$
m=-\operatorname{ctg}^{2} \nu ; \quad C=2 \operatorname{ctg} \nu ; \quad C=2 \sqrt{-m} .
$$

Corollary 1. When the stresses $\sigma_{1}$ and $\sigma_{2}$ generated by exterior loads satisfy $\sigma_{1} \approx$ $-\sigma_{2} \operatorname{ctg}^{2} \nu$, we have $K_{\text {incl }} \approx \infty$, that is, the main material behaves as a rigid body.

Proposition 2. Under the condition $|\tau|=k^{-}$the layer material is in a pure shear state.

Proof. For symmetry reasons, we have $\tau_{x z}=0$. The fluidity equation (4) and (6) yield

$$
\sigma_{x}=\sigma_{y}=\sigma_{z}=0 ; \quad \tau_{x y}=0 .
$$

The equilibrium equations in the inclined layer [5, p. 232] are

$$
\frac{\partial \sigma_{x}}{\partial x}+\frac{\partial \tau_{x y}}{\partial y}=0 ; \quad \frac{\partial \sigma_{y}}{\partial y}+\frac{\partial \tau_{x y}}{\partial x}=0
$$

From (9) and (10) we infer that $\sigma_{x}=\sigma_{y}=\sigma_{z}=0$ (here $\sigma=\left(\sigma_{x}+\sigma_{y}+\sigma_{z}\right) / 3$ is the hydrostatic stress). Hence, $\sigma_{y} a v=\sigma$. Since $\sigma_{y} a v=B \sigma_{2}$ by (2), it follows that $\sigma=0$. Thus, $\sigma_{x}=\sigma_{y}=\sigma_{z}=\tau_{x y}=\tau_{y z}=0$.

If $\sigma_{1}<0$ and $\sigma_{2}>0$, using (2), (6), and (8), we obtain

$$
\sigma_{1}=\frac{2 k^{-} m}{C}=-\sqrt{-m} k^{-}=(-\operatorname{ctg} \nu) k^{-} ; \quad \sigma_{2}=\frac{2 k^{-}}{C}=\frac{k^{-}}{\sqrt{-m}}=(\operatorname{tg} \nu) k^{-} .
$$


Similarly, for $\sigma_{1}>0$ and $\sigma_{2}<0$ condition (6) implies the equalities

$$
\sigma_{1}=\frac{2 k^{-} m}{C}=\sqrt{-m} k^{-}=(\operatorname{ctg} \nu) k^{-} ; \quad \sigma_{2}=\frac{-2 k^{-}}{C}=\frac{-k^{-}}{\sqrt{-m}}=(-\operatorname{tg} \nu) k^{-} .
$$

2. Equal Strength Conditions. Consider the conditions under which the weaker layer does not lower the strength of the joint. This occurs when the main material reaches the critical state simultaneously with the layer. For the critical state in the layer to be reached earlier than in the main material, it is necessary and sufficient that the critical values $\sigma_{1}$ and $\sigma_{2}$ of stresses satisfy at least one of the restrictions

$$
\left|\sigma_{1}\right| \leq 2 k^{+}, \quad\left|\sigma_{2}\right| \leq 2 k^{+}
$$

It follows from [7, p. 232] that (13) holds if and only if

$$
\frac{g}{\sqrt{B^{2}+g^{2} C^{2}}} \leq K \vee \frac{g|m|}{\sqrt{B^{2}+g^{2} C^{2}}} \leq K .
$$

If $m_{1} K C \geq 1$ then (14) holds. If $m_{1} K C<1$ then (14) is equivalent to the inequality

$$
g \leq \frac{m_{1} K B}{\sqrt{1-m_{1}^{2} K^{2} C^{2}}}, \quad m_{1}=\max \left(1 ; \frac{1}{|m|}\right) .
$$

This implies the following criterion of equal strength for a homogeneous sheet specimen and a specimen including a weaker layer:

Proposition 3. In order for the layer not to lower the strength of the joint, it is necessary and sufficient that $m_{1} K C \geq 1$ and the contact strengthening coefficient reach the value in the right-hand side of (15).

3. Finding the Parameter $k^{-}$. To calculate the bearing capacity of a sheet construction, we have to know the critical values of $k^{+}$and $k^{-}$. The parameter $k^{+}$, characterizing the main material of the sheet specimen, is calculated as in the seamless construction [3, 5]. The parameter $k^{-}$characterizes the state of the layer material at the moment when the stability of plastic deformation is lost. It is shown experimentally [8] that for complicated loading with simultaneous stretching and shear Ludwik's single curve hypothesis is confirmed in the form

$$
\sigma_{i}=f\left(\varepsilon_{i}\right),
$$

where $\sigma_{i}$ and $\varepsilon_{i}$ are the stress and deformation intensities respectively. Thus, we can apply this hypothesis for the layer material subject to similar loading. Assume that

$$
\sigma_{i}=A \varepsilon_{i}^{n}, \quad A=e^{n} n^{-n} \sigma_{B}
$$

Here $e$ is Euler's constant, $n$ is a parameter of the material characterizing its plastic properties $\left(0.1 \leq n \leq 0.3\right.$ in welded joints), and $\sigma_{B}$ is the strength of the material. Further arguments carry over easily to other approximations of the dependence (16) proposed in [5]. Assume that compression occurs in the direction of the action of $\sigma_{1}$, and stretching 
occurs in the direction of $\sigma_{2}$. Then it is obvious that $m=\sigma_{1} / \sigma_{2}<0$. The theory of small deformations yields

$$
\varepsilon_{i}=\frac{2 \varepsilon_{2} \sigma_{i}}{\sigma_{2}(2-m)}
$$

Since $\sigma_{2}=\left(2 g k^{-}\right) /\left(\sqrt{B^{2}+g^{2} C^{2}}\right)$ by [5], we infer from (18) that

$$
\varepsilon_{2}=\frac{\varepsilon_{i} \sigma_{2}(2-m)}{2 \sigma_{i}}=\frac{\varepsilon_{i} \sigma_{2}(2-m)}{2 \sqrt{3} k^{-}}=\frac{g(2-m) \varepsilon_{i}}{\sqrt{3} \sqrt{B^{2}+g^{2} C^{2}}}
$$

Denote by $h=h_{0} \exp \left(\varepsilon_{2}\right)$ the thickness of the layer in the direction of $\sigma_{2}$, where $h_{0}$ is the thickness of the layer at the initial moment of loading (see Fig. 1), by $t$ and $l$ the thickness and width of the sheet, and so $V=t l h$ is the volume of the layer, which is invariant in the deformation. Denote also by $N_{2}$ the exterior force acting in the direction of $\sigma_{2}$ at the critical moment of loading. Then

$$
\sigma_{2}=\frac{N_{2}}{t l}=\frac{N_{2} h}{V}=\frac{N_{2} h_{0}}{V} \exp \left(\varepsilon_{2}\right) .
$$

Thus, (19) implies that at the critical moment of loading

$\sigma_{i}=M \sigma_{2}=M \frac{N_{2} h_{0}}{V} \exp \left(\varepsilon_{2}\right)=M \frac{N_{2} h_{0}}{V} \exp \left(\frac{g(2-m) \varepsilon_{i}}{\sqrt{3} \sqrt{B^{2}+g^{2} C^{2}}}\right) ; \quad M=\frac{\sqrt{3} \sqrt{B^{2}+g^{2} C^{2}}}{2 g}$

Applying Swift's criterion [1], that is, equating the differentials of the right-hand sides of (17) and (20), we obtain the deformation intensity at the critical moment of loading:

$$
\varepsilon_{i}=\frac{\sqrt{3} n \sqrt{B^{2}+g^{2} C^{2}}}{g(2-m)} .
$$

Inserting the right-hand side of (21) into (17), we obtain the following assertion.

Proposition 4. At the critical moment of loading we can calculate the intensity of stresses, the parameter $k^{-}$, and the values of stresses of the exterior forces as

$$
\sigma_{i}=\left(\frac{\sqrt{3} e \sqrt{B^{2}+g^{2} C^{2}}}{g(2-m)}\right)^{n} \sigma_{B}^{-} ; \quad k^{-}=\frac{\sigma_{i}}{\sqrt{3}} ; \quad \sigma_{1}=m \sigma_{2} ; \quad \sigma_{2}=\frac{g(2-m) \sigma_{i}}{\sqrt{3} \sqrt{B^{2}+g^{2} C^{2}}} .
$$

Let us describe the algorithm for calculating the critical values of stresses of the exterior loadings. If the relative thickness $\chi$ of the layer is large, $\chi \geq 1$, then the contact strengthening of the layer is absent: $g=1$. In this case (22) is an explicit formula. For thin layers $g>1$. Then (5) and (22) are implicit formulas. Putting $g=1$ in (5) and (22), we can find the first approximations to the parameters $k^{-}$and $K$, and then $K_{\text {incl }}$. Knowing $K_{\text {incl }}$, we calculate the parameter $g$ using the algorithm of [7], and then apply (22) to find the second approximation for $k^{-}$. This enables us to launch an iterative process for calculating $\sigma_{1}$ and $\sigma_{2}$. On each step we calculate $K$ using (5) and check the equal strength condition (13) in the form (14). If it holds on some step then the calculation stops. Otherwise, the procedure stops when $g$ stabilizes. 
Conclusions. In this article we obtained an algorithm for calculating the critical values of stress and deformation in a layer and the critical values of exterior loadings in dependence on the specified parameters. When the thickness of the layer is comparable to or greater than that of the sheet, we gave explicit analytic expressions for these quantities. We studied the special case of weaker layer location in which the stressed state of the layer is a pure shear. We found conditions under which the weaker layer does not lower the strength of the joint.

\title{
References
}

1. Annin B.D., Zhigalkin V.M. Povedenie materialov v usloviyakh slozhnogo nagruzheniya [The Behavior of Materials Under Complex Loading]. Novosibirsk, Izdatel'stvo SO RAN, 1999.

2. Lebedev A.A., Koval'chuk B.I., Giginyak F.F., Lamashevskiy V.P. Mekhanicheskie svoystva konstruktsionnykh materialov $v$ usloviyakh slozhnogo napryazhennogo sostoyaniya [The Mechanical Properties of Structural Materials Under Complex Stress State]. Kiev, In Yure, 2003. (in Russian)

3. Koval'chuk G.I. [On the Question of Loss of Stability of the Plastic Deformation of Shells]. Strength of Materials, 1983, no. 5, pp. 11-16. (in Russian)

4. Swift H. Plastic Instability Under Plane Stress. Journal of the Mechanics and Physics of Solids, 1952, no. 1, pp. 1-18.

5. Dil'man V.L., Eroshkina T.V. Matematicheskoe modelirovanie kriticheskikh sostoyaniy myagkikh prosloek $v$ neodnorodnykh soedineniyakh [Mathematical Modelling of the Critical States of Soft Layers in Heterogeneous Connections]. Chelyabinsk, Publ. Center of the South Ural State University, 2011. (in Russian)

6. Kachanov L.M. [On the Strained State of the Plastic Interlayer]. Izvestiya akademii nauk SSSR. Otdelenie tekhnicheskikh nauk. Mekhanika i mashinostroenie, 1962, no. 5, pp. 63-67. (in Russian)

7. Dil'man V.L., Diyab A.N. The Stress State of a Strip With a Layer Under Considerable Mechanical Heterogeneity. Bulletin of the South Ural State University. Series: Mathematics. Mechanics. Physics, 2015, vol. 7, no. 4, pp. 11-19.(in Russian)

8. Tret'yakov M.P., Vil'deman V.E. Strain-Softening of Materials in the Plane Stress State Conditions. PNRPU Mechanics Bulletin, 2012, no. 2, pp. 190-203.(in Russian)

Received November 17, 2015

УДК 539.374

DOI: $10.14529 / \operatorname{mmp} 160110$

\section{КРИТИЧЕСКОЕ СОСТОЯНИЕ НАКЛОННОГО СЛОЯ В ЛИСТОВОМ ОБРАЗЦЕ ПРИ ОТРИЦАТЕЛЬНОМ КОЭФФИЦИЕНТЕ ДВУХОСНОСТИ НАГРУЖЕНИЯ}

\author{
В.Л. Дилъман, А.Н. Дияб
}

Исследуются условия потери устойчивости процесса пластического деформирования слоя из менее прочного материала в листовом образце. Слой не коллинеарен 
внешним силам, действующим в плоскости листа, ортогональным друг другу и имеющим разные знаки. Параметрами задачи являются: угол между слоем и направлением внешних сил; отношение напряжений, порождамых внешними силами; отношение пределов прочности материала слоя и основного материала листового образца; закон упрочнения материала слоя; отношение толщины слоя к толщине образца. На основе критерия Свифта пластической неустойчивости процесса деформирования материала слоя получен алгоритм для вычисления критической интенсивности напряжений в слое и критических внешних нагрузок в зависимости от указанных параметров. В случае отсутствия контактного упрочнения слоя полученные результаты имеют форму явных аналитических выражений. Найдены условия, при которых слой не снижает прочности образца. Найдены условия и исследован случай, когда напряженное состояние слоя является чистым сдвигом.

Ключевые слова: наклонный пластический слой; пластическая неустойчивость; напряженно-деформированное состояние; критерий Свифта.

\section{Литература}

1. Аннин, Б.Д. Поведение материалов в условиях сложного нагружения / Б.Д. Аннин, В.М. Жигалкин. - Новосибирск: Изд-во СО РАН, 1999.

2. Механические свойства конструкционных материалов в условиях сложного напряженного состояния / А.А. Лебедев, Б.И. Ковальчук, Ф.Ф. Гигиняк, В.П. Ламашевский. Киев: Ин Юре, 2003.

3. Ковальчук, Г.И. К вопросу о потере устойчивости пластического деформирования оболочек / Г.И. Ковальчук // Проблемы прочности. - 1983. - № 5. - С. 11-16.

4. Swift, H. Plastic instability under plane stress /H. Swift // Journal of the Mechanics and Physics of Solids. - 1952. - № 1. - P. 1-18.

5. Дильман, В.Л. Математическое моделирование критических состояний мягких прослоек в неоднородных соединениях / В.Л. Дильман, Т.В. Ерошкина. - Челябинск: Издат. центр ЮУрГУ, 2011.

6. Качанов, Л.М. О напряженном состоянии пластической прослойки / Л.М. Качанов // Изв. АН СССР. Отд. техн. наук. Механика и машиностроение. - 1962. - № 5. - С. 63-67.

7. Дильман, В.Л. Напряженное состояние полосы с прослойкой при значительной механической неоднородности / В.Л. Дильман, А.Н. Дияб // Вестник ЮУрГУ. Серия: Математика, механика, физика. - 2015. - Т. 7, № 4. - С. 11-19.

8. Третьяков, М.П. Деформационное разупрочнение материалов в условиях плоского напряженного состояния / М.П. Третьяков, В.Э. Вильдеман // Вестник ПНИПУ. Механика. - 2012. - № 2. - С. 190-203.

Валерий Лейзерович Дильман, доктор физико-математических наук, доцент, кафедра «Математический и функциональный анализ», Южно-Уральский государственный университет (г. Челябинск, Российская Федерация), Dilman49@mail.ru.

Аус Нидал Дияб, аспирант, кафедра «Прикладная математика», ЮжноУральский государственный университет (г. Челябинск, Российская Федерация), Aws.nth@gmail.com.

Поступила в редакиию 17 ноября 2015 г.

Вестник ЮУрГУ. Серия «Математическое моделирование

и программирование» (Вестник ЮУрГУ ММП). 2016. Т. 9, № 1. С. 123-129 